Mubarok, S. · S.D. Ananda $\cdot$ Farida $\cdot$ A. Fadilah $\cdot$ R. Sudirja

\title{
Evaluasi tiga sistem budidaya di lahan sempit pada budidaya dua kultivar bayam di kota Bekasi
}

Sari Budidaya sayuran pada lahan sempit di daerah perkotaan merupakan salah satu upaya pemerintah dalam mewujudkan ketahanan pangan. Tujuan dari penelitian ini adalah untuk mengetahui sistem budidaya tanaman bayam yang paling baik untuk diterapkan pada lahan sempit pekarangan di Kota Bekasi. Percobaan ini telah dilaksanakan pada bulan Agustus hingga September 2020 di areal pemukiman yang berlokasi di Jalan Caringin Raya, Kota Bekasi. Percobaan menggunakan metode Rancangan Acak Kelompok (RAK). Dua kultivar bayam, 'Maestro' dan 'Mira', dibudidayakan pada tiga sistem budidaya berbeda, yaitu konvensional, vertikultur, dan hidroponik rakit apung yang diulang sebanyak empat ulangan. Hasil penelitian menunjukkan bahwa penanaman bayam pada sistem hidroponik rakit apung menghasilkan pertumbuhan, hasil, kualitas hasil, serta pendapatan yang paling baik dibandingkan dengan sistem budidaya konvensional dan vertikultur.

Kata kunci: Hidroponik · Hortikultura · Sayuran · Vertikultur

\section{Evaluation of three cultivation systems in small scale of urban farming on two spinach cultivars in Bekasi city}

\begin{abstract}
Vegetable cultivation on limited areas in urban is one of the government's efforts to obtain food security. The purpose of this study was to determine the best amaranth cultivation system to be applied in urban farming system likewise on limited areas in Bekasi City. This experiment was carried out from August to September 2020 in a densely inhabited living area located on Caringin Raya Street, Bekasi. The experiment used a Randomized Block Design. Two cultivars amaranth, 'Maestro' and 'Mira' were cultivated under treatment of three different cultivation. There were conventional system, verticulture system, and hydroponic floating raft, that repeated four times. The results showed that amaranth cultivation on the floating raft hydroponic produced the best growth, yield, yield quality, and revenue, compared to conventional and verticulture cultivation systems.
\end{abstract}

Keywords: Hydroponic · Horticulture · Vegetables · Verticulture

Diterima : 31 Januari 2021, Disetujui : 27 Juli 2021, Dipublikasikan : 1 Agustus 2021 DOI: https:// doi.org/10.24198/kultivasi.v20i2.32022

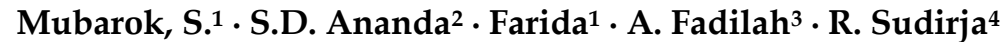

${ }^{1}$ Departemen Budidaya Pertanian, Fakultas Pertanian, Universitas Padjadjaran

${ }^{2}$ Program Studi Agroteknologi, Fakultas Pertanian, Universitas Padjadjaran

${ }^{3}$ Program Studi Agroteknopreneur, Fakultas Pertanian, Universitas Padjadjaran

${ }^{4}$ Departemen Ilmu Tanah dan Sumberdaya Lahan, Fakultas Pertanian Universitas Padjadjaran

Korespondensi: syariful.mubarok@unpad.ac.id
} 


\section{Pendahuluan}

Upaya untuk mewujudkan kemandirian pangan di Indonesia sudah dilakukan oleh Badan Ketahanan Pangan (BKP) Kementerian Pertanian (Kementan) melalui Program Pertanian Keluarga dan Pekarangan Lestari. Pemanfaatan lahan pekarangan rumah merupakan salah satu alternatif untuk mewujudkan kemandirian pangan dalam rumah tangga. Selain itu, sistem kemandirian pangan di rumah dapat dilakukan untuk memenuhi asupan nutrisi guna membangun sistem imun selama pandemi COVID-19 (Bulgari et al., 2021). Lahan pekarangan memiliki potensi sebagai penyedia bahan pangan keluarga, dan meningkatkan pendapatan keluarga (Ashari et al., 2012). Keterbatasan lahan di daerah perkotaan seperti Kota Bekasi yang disebabkan oleh pesatnya pembangunan menyebabkan rumah-rumah umumnya tidak mempunyai pekarangan yang layak untuk tempat budidaya tanaman, sehingga pertanian perkotaan merupakan alternatif untuk menyiasati keterbatasan lahan tersebut (Santoso dan Widya, 2014). Pertanian perkotaan merupakan kegiatan pertumbuhan, pengolahan, dan distribusi pangan serta produk lainnya melalui budidaya tanaman yang intensif di perkotaan dan daerah sekitarnya (Food and Agriculture Organization, 2008).

Lahan pertanian di Kota Bekasi telah banyak mengalami perubahan menjadi lahan pemukiman, perkantoran dan perbelanjaan, sehingga dengan kondisi lahan seperti itu perlu dicari sistem budidaya untuk lahan sempit, salah satunya menggunakan sistem hidroponik. Kota Bekasi berada pada ketinggian 11 - $81 \mathrm{~m}$ di atas permukaan air laut (dpl) dengan kemiringan 0 $2 \%$, dan temperatur harian diperkirakan berkisar antara $24-33^{\circ} \mathrm{C}$ (Pemerintah Kota Bekasi, 2020). Dengan kondisi lingkungan seperti itu, maka tanaman bayam merupakan salah satu sayuran yang dapat ditanam di dataran rendah. Tanaman bayam mempunyai daya adaptasi yang baik terhadap lingkungan tumbuh, sehingga dapat ditanam di dataran rendah seperti Kota Bekasi. Beberapa kultivar bayam yang sering dibudidayakan di Indonesia adalah Maestro yang berwarna hijau (bayam hijau) dan Mira yang berwarna merah (bayam merah).
Sistem budidaya tanaman yang dapat dilakukan di lahan sempit antara lain melalui sistem budidaya secara hidroponik, vertikal atau vertikultur dan budidaya dalam pot/polybag (Nappu dan Arief, 2012). Hidroponik meru- pakan suatu metode budidaya tanaman secara terkendali yang dapat dilakukan tanpa media tanam. Beberapa keuntungan dari metode hidroponik adalah tidak memerlukan lingkungan yang luas dibandingkan konvensional, kualitas dan kuantitas yang tinggi, efisiensi air, kondisi lingkungan tumbuh yang terkendali, serta dapat dilakukan sepanjang tahun jika kondisi mendukung (Barbosa et al., 2015).

Vertikultur merupakan salah satu teknik dalam budidaya tanaman dengan memanfaatkan suatu wadah untuk menampung tanaman dan disusun secara vertical, sehingga mampu mengurangi penggunaan lahan (Asharo, 2021). Teknik vertikultur ini mempunyai keuntungan untuk memaksimalkan lahan pekarangan serta memungkinkan warga perkotaan untuk menghasilkan produk tanaman tanpa memerlukan lahan yang luas seperti budiaya tanaman secara konvensional (Giriwari et al., 2018). Selain sebagai penghijauan lahan pekarangan, vertikultur dapat digunakan sebagai bidang karya seperti green wall ataupun sarana produksi tanaman yang disebut vertical farm meskipun perlu memperhitungkan berbagai aspek seperti pencahayaan, sistem pertumbuhan, distribusi nutrisi, konstruksi, dan efisiensi energi (Beacham et al., 2019). Jenis-jenis tanaman yang dapat dibudidayakan dengan teknik vertikultur pada umumnya jenis sayuran. Sistem budidaya tanaman secara vertikultur dapat dilakukan melalui teknik hidroponik yang akan menghasilkan kualitas sayuran yang lebih baik dibandingkan dengan sistem konvensional. Zulfitri (2005) menyatakan bahwa hasil tanaman dengan sistem hidroponik lebih bagus dibandingkan dengan tanaman secara konvensional, serta kualitas dan kuantitas tanaman lebih terkontrol.

Dengan melihat kelebihan dan kekurangan sistem budidaya tersebut, maka penelitian ini dilakukan untuk mengetahui pertumbuhan dan hasil dua kultivar bayam pada sistem budidaya konvensional (polybag), vertikultur, dan hidroponik rakit apung untuk lahan sempit pekarangan di Kota Bekasi. Hasil penelitian ini diharapkan dapat mendukung ketahanan pangan di masyarakat perkotaan. 


\section{Bahan dan Metode}

Percobaan dilaksanakan menggunakan screen house di pemukiman masyarakat di Jalan Caringin, Kota Bekasi yang berada pada ketinggian $\pm 19 \mathrm{~m} \mathrm{dpl}$ pada bulan Agustus - September 2020. Rancangan percobaan yang digunakan dalam percobaan ini adalah Rancangan Acak Sederhana, yang terdiri dari enam kombinasi perlakuan dua kultivar bayam, yaitu 'Maestro' (bayam hijau) dan 'Mira' (bayam merah) dan tiga sistem budidaya, yaitu konvensional, vertikultur dan hidroponik rakit apung, yang diulang sebanyak empat kali. Sampel setiap plot percobaan terdiri atas tiga lubang tanam yang masing-masing berisi tiga tanaman bayam. Pengamatan terdiri dari dua macam, yaitu pengamatan penunjang dan pengamatan utama.

Pengamatan penunjang meliputi:

a. Suhu harian rata-rata $\left({ }^{\circ} \mathrm{C}\right)$ dan kelembapan harian rata-rata (\%). Pengukuran suhu dan kelembapan menggunakan thermo-hygrometer, waktu pengukuran dilakukan sebanyak tiga kali pada pukul $08.00\left(t_{1}, R_{1}\right)$, pukul $13.00\left(t_{2}, R_{2}\right)$, dan pukul $17.00\left(t_{3}, R_{3}\right)$ (Handoko, 1994). Suhu dan kelembaban harian dihitung menggunakan rumus sebagai berikut :

Suhu udara harian $\left({ }^{\circ} \mathrm{C}\right)=\frac{2 \mathrm{t}_{1}+\mathrm{t}_{2}+\mathrm{t}_{3}}{4}$

Kelembaban udara harian $(\%)=\frac{2 \mathrm{Rh}_{1}+\mathrm{Rh}_{2}+\mathrm{Rh}_{3}}{4}$

b. Organisme pengganggu tanaman. Pengamatan serangan organisme pengganggu tanaman dilakukan mulai dari awal penanaman hingga akhir percobaan. Pengamatan ini dilakukan untuk melihat apa saja jenis OPT yang menyerang tanaman serta gejala yang ditimbulkan pada tanaman.

Sedangkan pengamatan utama meliputi:

a. Jumlah Daun. Penghitungan jumlah daun tanaman dilakukan pada saat tanaman berumur 0 hari setelah pindah tanam (HSPT), 7 HSPT, 14 HSPT, dan 18 HSPT. Daun tanaman yang dihitung adalah semua daun yang sudah tumbuh dan membuka.

b. Tinggi Tanaman. Pengukuran tinggi tanaman dilakukan dengan cara mengukur tinggi tanaman bayam mulai dari pangkal tanaman hingga puncak tertinggi daun. Pengukuran tinggi tanaman dilakukan pada saat tanaman berumur $0 \mathrm{HSPT}, 7 \mathrm{HSPT}$, $14 \mathrm{HSPT}$, dan 18 HSPT.

c. Diameter Batang. Pengukuran diameter batang tanaman dilakukan dengan cara menghitung diameter batang tanaman pada ketinggian $5 \mathrm{~cm}$ dari permukaan tanah dengan menggunakan jangka sorong. Pengukuran diameter batang dilakukan pada saat tanaman berumur 7 HSPT, 14 HSPT, dan 18 HSPT.

d. Luas Daun. Pengukuran luas daun tanaman dilakukan setelah pemanenan dengan metode gravimetri, sebagai berikut :

$$
\text { Luas daun }=\frac{\text { bobot replika daun }}{\text { bobot kertas } 1 \times 1 \mathrm{~cm}^{2}} \times 1 \mathrm{~cm}^{2}
$$

e. Panjang Akar. Pengukuran panjang akar dilakukan setelah pemanenan. Pengukuran panjang akar dilakukan dengan mengukur akar dari pangkal tanaman sampai akar tanaman terpanjang menggunakan penggaris.

f. Volume Akar. Pengukuran volume akar dilakukan segera setelah pemanenan. Pengukuran volume akar diukur dengan cara mencuci akar tanaman hingga bersih, kemudian akar di potong lalu dimasukkan ke dalam gelas ukur dan mengamati selisih volume air antara setelah dimasukkan akar dengan volume air awal sebelum dimasukkan akar.

g. Bobot Segar Tanaman. Pengukuran bobot segar tanaman dilakukan segera setelah pemanenan. Bobot segar yaitu berat keseluruhan bagian tanaman segar tanpa pengeringan. Akar, batang, dan daun tanaman yang telah dicuci, ditiriskan. Air yang masih melekat di angin-anginkan lalu timbang secara keseluruhan

h. Persentase Layak Pasar. Pengamatan hasil layak pasar bayam diperoleh dari pengukuran bobot segar tanaman, tangkai yang tidak liat, dan bagian tangkai/daun yang rusak tidak melebihi 10\% (Samad, 2006). Persentase hasil layak pasar (PHLP) dihitung setelah keseluruhan tanaman dipanen dan dihitung menggunakan rumus : 


$$
\text { PHLP }=\frac{\text { bobot layak pasar }}{\text { bobot total }} \times 100 \%
$$

i. Umur Panen. Pengamatan umur panen tanaman bayam diperoleh dari pencatatan umur pemanenan tanaman. Tanaman bayam dipanen saat tanaman sudah mencapai kriteria tinggi yaitu $25-30 \mathrm{~cm}$ untuk Kultivar Maestro dan 21-23 cm untuk Kultivar Mira.

j. Analisis Usaha Tani, Analisis usaha tani dihitung besarnya biaya investasi usaha, penerimaan dari produksi tanaman bayam, dan payback period dari sistem budidaya konvensional, vertikultur, dan hidroponik rakit apung. Payback Period (PP) menurut Muchtar (2010), yaitu:

\begin{tabular}{ll}
\multicolumn{1}{c|}{$\mathrm{PP}=$} & \multicolumn{1}{c}{ Investasi } \\
& Kas Masuk Bersih \\
$\mathrm{PP}$ & Payback Period (Bulan) \\
Investasi & Modal $($ Rp) \\
Kas Masuk Bersih $=$ & Keuntungan/pendapat- \\
& an bersih (Rp/bulan)
\end{tabular}

Pengaruh perlakuan terhadap pertumbuhan dan hasil tanaman bayam dianalisis menggunakan analisis ragam (ANOVA) pada taraf nyata $5 \%$. Apabila terdapat perbedaan antara perlakuan, analisis dilanjutkan menggunakan uji Tukey (HSD) pada taraf nyata $5 \%$ dengan menggunakan program SPSS.

\section{Hasil dan Pembahasan}

Suhu, Kelembaban, dan Serangan Organisme Pengganggu Tanaman. Suhu dan kelembaban rata-rata di dalam screen house pada saat penelitian masing-masing yaitu $29,49^{\circ} \mathrm{C}$ dan $65,58 \%$. Rata-rata suhu dan kelembaban di dalam screen house selama dilakukan penelitian tergolong cukup tinggi untuk pertanaman bayam. Untuk menjaga pertumbuhan bayam selalu baik, maka kebutuhan suhu optimum untuk pertumbuhan tanaman bayam berkisar antara 17 - $28{ }^{\circ} \mathrm{C}$ serta kelembapan udara $50-60 \%$ (Lingga, 2009). Suhu yang tinggi akan merusak tanaman serta dapat menyebabkan laju transpirasi meningkat, sedangkan kelembaban yang tinggi pada tanaman akan menghindari evaporasi yang terlalu tinggi.

Selama proses pertumbuhan tanaman mulai dari tanaman sampai dengan panen, muncul gangguan akibat organisme pengganggu tanaman (OPT). OPT yang banyak menyerang kutu daun (Myzus persicae), gejala yang disebabkan yaitu daun bayam melengkung dan berpilin. Keberadaan hama kutu daun dapat disebabkan karena kandungan nitrogen pada daun bayam cukup tinggi sehingga mengeluarkan senyawa volatil yang mampu menarik perhatian hama (Ahmed et al., 2019). Hama lain yang menyerang adalah penggorok daun (Liriomyza chinensis), gejala yang disebabkan yaitu terdapatnya liang korokan beralur warna putih bening pada bagian mesofil daun.

Intensitas serangan organisme pengganggu tanaman bayam pada sistem budidaya konvensional, vertikultur, dan hidroponik rakit apung secara berurutan sebesar 38,89\%, 50,00\%, dan $22,20 \%$. Intensitas serangan organisme pengganggu tanaman bayam yang paling kecil terdapat pada hidroponik rakit apung, sedangkan untuk yang paling besar terdapat pada sistem budidaya vertikultur. Tingginya serangan OPT pada vertikultur diduga karena tingginya densitas tanaman bayam dalam suatu rangkaian tanaman sehingga memungkinkan terjadinya kontak antar tanaman sehingga membuka peluang untuk OPT menular ke tanaman lain (Harshana et al., 2017). Serangan OPT dapat menyebabkan produktivitas tanaman menjadi menurun, baik kualitas maupun kuantitas (Septiariani et al., 2019). Pengamatan dan pengendalian rutin serangan organisme pengganggu tanaman pada tanaman bayam dilakukan untuk mengurangi serangan OPT.

Pertumbuhan Tanaman. Jumlah daun dari pengaruh sistem budidaya konvensional, vertikultur, dan hidroponik rakit apung berpengaruh secara signifikan mulai dari tanaman bayam umur 7 HSPT sampai 18 HSPT untuk Kultivar Maestro dan 14 HSPT sampai 18 HSPT untuk Kultivar Mira. Apabila dilihat pada Tabel 1, jumlah daun dua kultivar tanaman bayam pada sistem hidroponik rakit apung memiliki nilai rata-rata terbanyak yaitu 15,78 helai untuk Kultivar Maestro dan 12,78 helai untuk Kultivar Mira. Jumlah daun paling sedikit terdapat pada sistem budidaya vertikultur yaitu 8,86 helai untuk Kultivar Maestro dan 8,72 helai untuk Kultivar Mira.

Tabel 1. Pengaruh tiga sistem budidaya terhadap jumlah daun tanaman bayam Kultivar Maestro dan Mira 


\begin{tabular}{lllllll}
\hline \multicolumn{2}{c}{ Perlakuan } & & \multicolumn{3}{c}{ Jumlah daun (helai) } \\
\cline { 1 - 2 } \cline { 5 - 6 } Kultivar & $\begin{array}{l}\text { Sistem Budi- } \\
\text { daya }\end{array}$ & & 7 & 14 & 18 \\
& Maestro & Konvensional & & $6,25 \mathrm{~b}$ & $10,56 \mathrm{~b}$ & $10,72 \mathrm{~b}$ \\
Maestro & Vertikultur & & $5,28 \mathrm{a}$ & $8,58 \mathrm{a}$ & $8,86 \mathrm{a}$ \\
Maestro & Rakit Apung & & $7,56 \mathrm{c}$ & $14,33 \mathrm{e}$ & $15,78 \mathrm{~d}$ \\
Mira & Konvensional & & $6,29 \mathrm{~b}$ & $11,69 \mathrm{c}$ & $12,64 \mathrm{c}$ \\
Mira & Vertikultur & & $5,78 \mathrm{ab}$ & $7,92 \mathrm{a}$ & $8,72 \mathrm{a}$ \\
Mira & Rakit Apung & & $6,36 \mathrm{~b}$ & $12,42 \mathrm{~d}$ & $12,78 \mathrm{c}$ \\
\hline
\end{tabular}

Keterangan: Angka yang diikuti dengan huruf yang sama ke arah vertikal menunjukkan tidak berbeda nyata menurut uji Tukey pada taraf nyata $5 \%$.

Perlakuan sistem budidaya memengaruhi tinggi kedua kultivar tanaman bayam sehingga menghasilkan tinggi tanaman yang berbeda-beda pada masing-masing sistem budidaya (Gambar 2 dan Tabel 2). Berdasarkan analisis ragam yang diperoleh, pengaruh sistem budidaya konvensional, vertikultur, dan hidroponik rakit apung berpengaruh secara signifikan terhadap tinggi tanaman bayam, mulai dari umur 14 HSPT sampai 18 HSPT. Tinggi tanaman dua kultivar tanaman bayam pada sistem hidroponik rakit apung memiliki nilai rata-rata terbesar yaitu $24,82 \mathrm{~cm}$ untuk Kultivar Maestro dan 8,62 helai untuk Kultivar Mira. Tinggi tanaman terendah terdapat pada sistem budidaya vertikultur yaitu $12,33 \mathrm{~cm}$ untuk Kultivar Maestro dan 8,62 cm untuk Kultivar Mira.

Pengaruh sistem budidaya konvensional, vertikultur, dan hidroponik rakit apung berpengaruh secara signifikan terhadap jumlah daun, mulai dari tanaman bayam umur 7 HSPT sampai 18 HSPT. Diameter batang pada sistem hidroponik rakit apung memiliki nilai rata-rata terbesar yaitu 6,45 mm untuk Kultivar Maestro

dan 6,05 mm untuk Kultivar Mira. Diameter batang terendah terdapat pada sistem budidaya vertikultur yaitu 2,82 mm pada Kultivar Maestro dan 2,53 mm Kultivar Mira (Tabel 3).

Tabel 2. Pengaruh tiga sistem budidaya terhadap tinggi tanaman tanaman bayam Kultivar Maestro dan Mira

\begin{tabular}{llllll}
\hline \multicolumn{2}{c}{ Perlakuan } & & \multicolumn{3}{c}{ Tinggi tanaman $(\mathrm{cm})$} \\
\cline { 1 - 2 } \cline { 5 - 6 } Kultivary & \multirow{2}{*}{ Sistem Budidaya } & & 7 & 14 & 18 \\
& & & HSPT & HSPT & HSPT \\
\hline Maestro & Konvensional & & $6,83 \mathrm{~b}$ & $12,69 \mathrm{~b}$ & $16,65 \mathrm{c}$ \\
Maestro & Vertikultur & & $5,44 \mathrm{a}$ & $10,93 \mathrm{~b}$ & $12,33 \mathrm{~b}$ \\
Maestro & Rakit Apung & & $7,98 \mathrm{c}$ & $17,46 \mathrm{~d}$ & $24,82 \mathrm{e}$ \\
Mira & Konvensional & & $6,62 \mathrm{~b}$ & $12,77 \mathrm{bc}$ & $17,38 \mathrm{c}$ \\
Mira & Vertikultur & & $6,66 \mathrm{~b}$ & $7,10 \mathrm{a}$ & $8,62 \mathrm{a}$ \\
Mira & Rakit Apung & & $7,12 \mathrm{~b}$ & $14,23 \mathrm{c}$ & $19,19 \mathrm{~d}$ \\
\hline
\end{tabular}

Keterangan: Angka yang diikuti dengan huruf yang sama ke arah vertikal menunjukkan tidak berbeda nyata menurut uji Tukey pada taraf nyata $5 \%$.

Tabel 3. Pengaruh tiga sistem budidaya terhadap diameter batang tanaman bayam Kultivar Maestro dan Mira

\begin{tabular}{|c|c|c|c|c|}
\hline \multicolumn{2}{|c|}{ Perlakuan } & \multicolumn{3}{|c|}{ Diameter batang $(\mathrm{mm})$} \\
\hline \multirow{2}{*}{ Kultivar } & \multirow{2}{*}{ Sistem Budidaya } & 7 & 14 & 18 \\
\hline & & HSPT & HSPT & HSPT \\
\hline Maestro & Konvensional & $2,34 b c$ & $3,77 \mathrm{c}$ & $5,79 b$ \\
\hline Maestro & Vertikultur & $2,03 a b$ & $2,64 b$ & $2,82 \mathrm{a}$ \\
\hline Maestro & Rakit Apung & $3,19 d$ & $4,36 \mathrm{~d}$ & $6,45 b$ \\
\hline Mira & Konvensional & $2,64 c$ & $3,46 c$ & $6,09 b$ \\
\hline Mira & Vertikultur & $1,56 a$ & $2,04 a$ & $2,53 a$ \\
\hline Mira & Rakit Apung & $2,56 b c$ & $3,46 \mathrm{c}$ & $6,05 b$ \\
\hline \multicolumn{5}{|c|}{$\begin{array}{l}\text { Keterangan: Angka yang diikuti dengan huruf } \\
\text { yang sama ke arah vertikal menunjukkan tidak } \\
\text { berbeda nyata menurut uji Tukey pada taraf nyata } \\
5 \% \text {. }\end{array}$} \\
\hline
\end{tabular}

Tabel 4. Pengaruh tiga sistem budidaya terhadap luas daun, panjang akar, dan volume akar tanaman bayam Kultivar Maestro dan Mira

\begin{tabular}{|c|c|c|c|c|}
\hline \multicolumn{2}{|c|}{ Perlakuan } & \multirow[t]{2}{*}{ Luas daun $\left(\mathrm{cm}^{2}\right)$} & \multirow{2}{*}{$\begin{array}{l}\text { Panjang akar } \\
(\mathrm{cm})\end{array}$} & \multirow{2}{*}{$\begin{array}{l}\text { Volume akar } \\
\text { (mL) }\end{array}$} \\
\hline Kultivar & Sistem Budidaya & & & \\
\hline Maestro & Konvensional & $26,06^{c}$ & $214,46 \mathrm{~d}$ & $6,67 b$ \\
\hline Maestro & Vertikultur & $15,63^{b}$ & $140,83 b$ & $5,50 \mathrm{ab}$ \\
\hline Maestro & Rakit Apung & $41,05^{\mathrm{e}}$ & $480,02 f$ & $15,92 \mathrm{c}$ \\
\hline Mira & Konvensional & $17,44^{\mathrm{b}}$ & $171,32 \mathrm{c}$ & $4,33 \mathrm{ab}$ \\
\hline Mira & Vertikultur & $9,43^{\mathrm{a}}$ & $60,99 a$ & $3,08 \mathrm{a}$ \\
\hline Mira & Rakit Apung & $29,08^{\mathrm{d}}$ & $228,53 \mathrm{e}$ & $14,75 c$ \\
\hline
\end{tabular}

Keterangan: Angka yang diikuti dengan huruf yang sama ke arah vertikal menunjukkan tidak berbeda nyata menurut uji Tukey pada taraf nyata $5 \%$. 


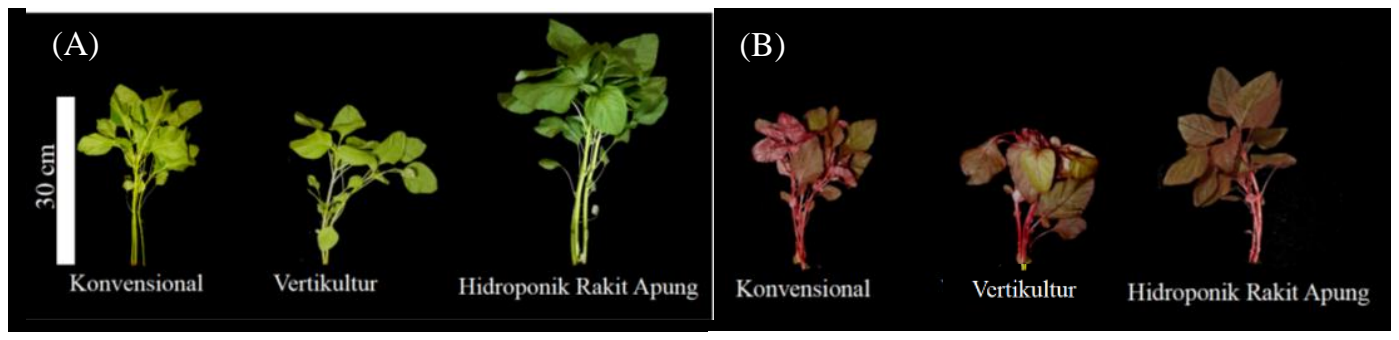

Gambar 2. Penampilan tanaman bayam kultivar Maestro (A) dan Mira (B) pada 18 HSPT dari tiga sistem budidaya berbeda

Luas daun dua kultivar tanaman bayam yang ditanam pada sistem budidaya konvensional, vertikultur, dan hidroponik rakit apung berbeda secara signifikan. Luas daun dua kultivar tanaman bayam pada sistem hidroponik rakit apung memiliki nilai rata-rata terbesar yaitu 480,02 $\mathrm{cm}^{2}$ untuk Kultivar Maestro dan 228,53 $\mathrm{cm}^{2}$ untuk Kultivar Mira. Luas daun terendah terdapat pada sistem budidaya vertikultur yaitu $140,83 \mathrm{~cm}^{2}$ untuk Kultivar Maestro dan 60,99 $\mathrm{cm}^{2}$ untuk Kultivar Mira (Tabel 4). Demikian juga untuk panjang akar dan volume akar. panjang akar dua kultivar tanaman bayam pada sistem hidroponik rakit apung memiliki nilai rata-rata terbesar yaitu 41,05 cm untuk Kultivar Maestro dan 29,08 cm untuk Kultivar Mira. Panjang akar terendah terdapat pada sistem budidaya vertikultur yaitu 15,63 cm untuk Kultivar Maestro dan 9,43 cm untuk Kultivar Mira. Volume akar dua kultivar tanaman bayam pada sistem hidroponik rakit apung memiliki nilai rata-rata $15,92 \mathrm{ml}$ untuk Kultivar Maestro dan 14,75 ml untuk Kultivar Mira. Volume akar pada sistem budidaya vertikultur yaitu 5,50 ml untuk Kultivar Maestro dan 3,08 ml untuk Kultivar Mira.

Percobaan ini menunjukkan bahwa pertumbuhan kedua kultivar tanaman bayam yang dibudidayakan dengan sistem hidroponik rakit apung memiliki hasil yang sangat baik, ditunjukkan pada jumlah daun, tinggi tanaman, diameter batang, luas daun, panjang akar, dan volume akar yang lebih baik bila dibandingkan dengan sistem budidaya lainnya. Pertumbuhan tanaman yang optimal dipengaruhi oleh beberapa faktor seperti unsur hara, air, oksigen, cahaya, suhu, dan kelembapan. Pada sistem budidaya yang berbeda, terdapat pula perbedaan ketersediaan faktor-faktor pendukung pertumbuhan dan perkembangan tanaman. Proses respirasi akar yang optimal akan menghasilkan energi akar sehingga akar dapat menyerap nutrisi hidroponik secara maksimal (Fauzi et al., 2013). Kekurangan oksigen pada aktivitas sistem perakaran menyebabkan permeabilitas membran sel menurun, sehingga dinding sel makin sukar untuk ditembus (Morard dan Silvestre, 1996). Hal ini memengaruhi terjadinya proses penyerapan air dan mineral hara.

Pada sistem budidaya hidroponik, air menjadi media utama sehingga pasokan air selalu tersedia untuk tanaman. Fertigasi dengan otomatisasi lebih efektif dalam meningkatkan pertumbuhan dan produksi tanaman selada. Sejalan dengan hasil penelitian Iqbal (2006) yang menunjukkan bahwa fertigasi otomatis meningkatkan pertumbuhan dan produksi tanaman bayam. Fertigasi bayam secara terputus-putus, terus-menerus, dan manual menghasilkan bobot segar tanaman sebesar 40,95; 41,00; dan 34,63 g.

Pada penelitian ini terlihat bahwa pertanaman dua kultivar bayam yang dibudidayakan dengan sistem budidaya vertikultur menunjukkan hasil terendah bila dibandingkan dengan sistem budidaya lainnya. Hal serupa diperlihatkan dari hasil penelitian Andrian (2018) yang menunjukkan bahwa pertumbuhan dan perkembangan tanaman pada sistem vertikultur akan menurun pada keadaan kekurangan intensitas cahaya. Kekurangan intensitas cahaya akan memengaruhi proses fotosintesis oleh tanaman. Proses fotosintesis yang terganggu menyebabkan pembentukan senyawa-senyawa kompleks untuk proses respirasi menjadi tidak optimal sehingga energi yang dibutuhkan untuk aktivitas metabolisme menjadi tidak maksimal.

\section{Hasil Tanaman}

Bobot Segar Tanaman. Berdasarkan analisis ragam yang diperoleh, didapatkan bahwa bobot segar dua kultivar tanaman bayam dari pengaruh sistem budidaya konvensional, 
vertikultur, dan hidroponik rakit apung berpengaruh secara signifikan. Apabila dilihat pada Tabel 5, bobot segar dua kultivar tanaman bayam pada sistem hidroponik rakit apung memiliki nilai rata-rata terbesar yaitu 53,31 g untuk Kultivar Maestro yang berbeda nyata dengan perlakuan lainnya. Bobot segar tanaman terendah terdapat pada kultivar Mira dengan sistem budidaya vertikultur.

Demikian juga untuk persentase layak pasar dan umur panen, sistem hidroponik rakit apung memberikan pengaruh terbaik (Tabel 5). Persentase layak pasar dua kultivar tanaman bayam pada sistem hidroponik rakit apung memiliki nilai rata-rata terbesar yaitu $87,26 \%$ untuk Kultivar Maestro dan 88,71\% untuk Kultivar Mira. Persentase layak pasar terendah terdapat pada sistem budidaya vertikultur yaitu 53,39\% untuk Kultivar Maestro dan 36,71\% untuk Kultivar Mira. Umur panen dua kultivar tanaman bayam pada sistem hidroponik rakit apung memiliki nilai rata-rata paling cepat yaitu 17,42 HSPT untuk Kultivar Maestro dan Mira. Umur panen tanaman paling lambat terdapat pada sistem budidaya vertikultur yaitu 23,00 HSPT untuk Kultivar Maestro dan 25,75 HSPT untuk Kultivar Mira.

Analisis Usaha Tani. Analisis usaha tani tanaman bayam Kultivar Maestro dan Kultivar Mira (Tabel 10) dari pengaruh sistem budidaya konvensional, vertikultur, dan hidroponik rakit apung cenderung berbeda. Pendapatan dari sistem rakit apung pada kedua varietas bayam memiliki nilai tertinggi daripada sistem konvensional dan vertikultur. Nilai PP sistem budidaya konvensional adalah paling cepat pada kultivar Maestro dan sistem vertikultur adalah paling lama, sementara pada kultivar Mira, sistem hidroponik rakit apung memiliki nilai PP paling cepat dan sistem vertikultur paling lama.
Sistem budidaya tanaman yang dapat digunakan untuk meningkatkan baik kuantitas maupun kualitas hasil adalah sistem hidroponik. Kepadatan tanaman per satuan luas pada budidaya di sistem hidroponik dapat dilipatgandakan sehingga menghemat penggunaan lahan. Hal tersebut sejalan dengan penelitian Wachjar dan Anggayuhlin (2013) bahwa populasi besar dapat meningkatkan produktivitas per satuan luas dibandingkan dengan populasi sedikit. Kualitas hasil dari budidaya pada sistem hidroponik juga lebih baik dibandingkan secara konvensional (Indriasti, 2013). Hal tersebut disebabkan sistem hidroponik memberikan kondisi lingkungan pertumbuhan yang terkendali serta sistem pemberian nutrisi pada tanaman yang lebih efektif baik dalam bentuk pupuk yang digunakan, kondisi $\mathrm{pH}$ air, maupun EC air sehingga mempermudah perakaran tanaman untuk menyerap unsur hara (Kulkarni et al., 2018). Kualitas sayuran yang tinggi dilihat dari persentase hasil layak pasar (Tabel 5). Sayuran hidroponik memiliki kualitas yang lebih segar dan lebih bersih bila dibandingkan dengan sayuran konvensional.

Sayuran hidroponik memiliki pasar khusus yang membuat sayuran hidroponik dapat dijual dengan harga yang jauh lebih tinggi dibandingkan dengan sayuran konvensional. Penggunaan sistem hidroponik membutuhkan biaya yang tinggi dalam produksinya, akan tetapi kualitas hasil panen yang lebih baik mengakibatkan harga sayuran hidroponik lebih mahal. Nilai payback period pada kultivar Mira juga lebih cepat dibandingkan dengan budidaya tanaman secara konvensional dan vertikultur (Tabel 6).

Tabel 5. Pengaruh tiga sistem budidaya terhadap bobot segar tanaman, persentase layak pasar, dan umur panen tanaman bayam Kultivar Maestro dan Mira

\begin{tabular}{|c|c|c|c|c|}
\hline \multicolumn{2}{|c|}{ Perlakuan } & \multirow{2}{*}{$\begin{array}{l}\text { Bobot segar } \\
\text { tanaman }(g)\end{array}$} & \multirow{2}{*}{$\begin{array}{l}\text { Persentase layak } \\
\text { pasar }(\%)\end{array}$} & \multirow{2}{*}{$\begin{array}{l}\text { Umur Panen Tanaman } \\
\text { (HSPT) }\end{array}$} \\
\hline Kultivar & Sistem Budidaya & & & \\
\hline Maestrc & Konvensional & $34,5 \mathrm{c}$ & $64,49 b$ & $20,58 b$ \\
\hline Maestrc & Vertikultur & $32,71 \mathrm{c}$ & $53,39 b$ & $23,00 \mathrm{c}$ \\
\hline Maestrc & Rakit Apung & $53,31 \mathrm{e}$ & $87,26 c$ & $17,42 \mathrm{a}$ \\
\hline Mira & Konvensional & $22,18 b$ & $83,83 b$ & $22,67 \mathrm{c}$ \\
\hline Mira & Vertikultur & $17,00 \mathrm{a}$ & $36,71 \mathrm{a}$ & $25,75 d$ \\
\hline Mira & Rakit Apung & $42,59 \mathrm{~d}$ & $88,71 \mathrm{c}$ & $17,42 \mathrm{a}$ \\
\hline
\end{tabular}

Keterangan: Angka yang diikuti dengan huruf yang sama ke arah vertikal menunjukkan tidak berbeda nyata menurut uji Tukey pada taraf nyata $5 \%$ 
Tabel 6. Kriteria investasi budidaya tanaman bayam Kultivar Maestro

\begin{tabular}{cccc}
\hline \multirow{2}{*}{ Kriteria Investasi } & \multicolumn{3}{c}{ Sistem Budidaya } \\
\cline { 2 - 4 } & Konvensional & Vertikultur & Hidroponik Rakit Apung \\
\hline Kultivar Maestro & 0,62 & 0,58 & 0,95 \\
Produksi (Kg) & 56.700 & 102.100 & 150.135 \\
Nilai Investasi (Rp) & 12.425 & 11.773 & 23.988 \\
Penerimaan (Rp/Bulan) & 4,56 & 8,67 & 6,25 \\
Payback Period (Bulan) & & & 0,76 \\
\hline Kultivar Mira & 0,39 & 0,30 & 150.135 \\
Produksi (Kg) & 56.700 & 102.100 & 39.867 \\
Nilai Investasi (Rp) & 12.375 & 9.485 & 3,76 \\
Penerimaan (Rp/Bulan) & 4,58 & 10,76 & \\
Payback Period (Bulan) & & & \\
\hline
\end{tabular}

Keterbatasan lahan di daerah perkotaan menyebabkan lahan yang dimiliki harus dimanfaatkan secara tepat dan benar. Ashari et al. (2012) menyatakan rancangan pemanfaatan pekarangan yang lebih komprehensif diperlukan untuk mengoptimalkan peran lahan pekarangan sebagai penyangga ketahanan pangan rumah tangga. Santoso dan Widya (2014) menyatakan pertanian perkotaan dapat meningkatkan kemandirian masyarakat terutama menjaga ketahanan pangan dalam skala rumah tangga. Sistem hidroponik tidak membutuhkan lahan yang luas dalam pelaksanaannya serta menghasilkan tanaman yang lebih baik dari segi pertumbuhan dan hasilnya membuat penanaman pada sistem hidroponik rakit apung cocok untuk diterapkan pada lahan sempit pekarangan di Kota Bekasi.

\section{Kesimpulan}

1. Terdapat perbedaan pertumbuhan dan hasil dua kultivar bayam pada sistem budidaya konvensional (polybag), vertikultur, dan hidroponik rakit apung pada lahan sempit pekarangan di Kota Bekasi.

2. Sistem budidaya tanaman bayam dengan hidroponik rakit apung menunjukkan hasil yang tebaik pada kedua kultivar tanaman bayam dari parameter jumlah daun, tinggi tanaman, diameter batang, luas daun, panjang akar, volume akar, dan bobot segar sebesar 53,31 g pada Kultivar Maestro dan 42,59 g pada Kultivar Mira, persentase hasil layak pasar sebesar $87,26 \%$ pada Kultivar Maestro dan 88,71\% pada Kultivar Mira, umur panen 17,42 HSPT untuk kedua kultivar, dan pendapatan paling tinggi jika dibandingkan dengan sistem budidaya konvensional dan vertikultur.

\section{Daftar Pustaka}

Ahmed, N., H.L.C. Darshanee, I.A. Khan, Z.F. Zhang, and T.X. Liu. 2019. Host selection behavior of the green peach aphid, Myzus persicae, in response to volatile organic compounds and nitrogen contents of cabbage cultivars. Frontier in Plant Science, 10(79): 1-12

Andrian, N., Mariati, dan F. E. T. Sitepu. 2018. Pertumbuhan dan Produksi Bawang Merah (Allium ascalonicum L.) pada Pemberian Hidrogel dan Frekuensi Penyiraman dengan Sistem Vertikultur. Jurnal Agroekoteknologi FP USU, 6(2): 286-293

Ashari, Saptana, dan T. B. Purwantini. 2012. Potensi dan Pemanfaatan Lahan Pekarangan Untuk Ketahanan Pangan. Forum Penelitian Agro Ekonomi. 30 (1): 13-30. Retrieved from http:/ / pse.litbang.pertanian.go.i d/ind/pdffiles/FAE30-1b.pdf.

Asharo, R. K., E. Lisanti, R. Indrayanti, Adisyahputra, P.O. Pasaribu, R. Priambodo, V. Rizkawati, and Y. Irnidayanti. 2021. Cultivation of family medicinal plants using the verticulture method as efforts to use narrow yard land in Rawamangun, East Jakarta. Jurnal Pemberdayaan Masyarakat Madani, 5(1):61-74

Barbosa, G.L., F.D.A. Gadelha, N. Kublik, A. Proctor, L. Reichelm, E. Weissinger, G.M. Wohlleb, and R.U. Halden. 2015. Compari- 
son of land, water, and energy requirements of lettuce grown using hydroponic vs. Conventional agricultural methods. Int. J. Environ. Res. Public Health, 12: 6879-6891

Beacham, A.M., L.H. Vickers, and J.M. Monaghan. 2019. Vertical farming: a summary of approaches to growing skywards. Journal of Horticultural Science and Biotechnology, 94(3): 277-283

Bulgari, R., A. Petrini, G. Cocetta, C. Nicoletto, A. Ertani, P. Sambo, A. Ferrante, and S. Nicola. 2021. The Impact of COVID-19 on horticulture: critical issues and opportunities derived from an unexpected occurrence. Horticulturae, 7(124): 1-17

Fauzi R., E. T. S. Putra, dan E. Ambarwati. 2013. Pengayaan Oksigen di Zona Perakaran Untuk Meningkatkan Pertumbuhan dan Hasil Selada (Lactuca sativa L.) Secara Hidroponik. Fakultas Pertanian Universitas Gadjah Mada, Yogyakarta. Vegetalika 2(4): 63-74.

Food and Agriculture Organization. 2008. Urban Agriculture For Sustainable Poverty Alleviation and Food Security. 84p.

Giriwati, N.S.S., A. Citraningrum, and I. Setyabudi. 2018. Urban farming: people preference towards verticulture model in small housing type-settlements in Malang as sustainable landscape movement. IOP Conf. Series: Earth and Environmental Science, 179: 1-18

Handoko. 1994. Dasar Penyusunan dan Aplikasi Model Simulasi Komputer Untuk Pertanian. Institut Pertanian Bogor. Bogor. 104 hlm

Harshana, A., S.B. Patil, and S.S. Udikeri. 2017. Validation of existing IPM module of cotton under high density planting system. Journal of Entomology and Zoology Studies, 5(5): 687-690

Indriasti, R. 2013. Analisis Usaha Sayuran Hidroponik pada PT Kebun Sayur.

Iqbal, M. 2006. Penggunaan Pupuk Majemuk Sebagai Sumber Hara pada Budidaya Bayam Secara Hidroponik dengan Tiga Fertigasi. Skripsi. Departemen Agronomi dan Hortikultura. Fakultas Pertanian. Institut Pertanian Bogor. Bogor.
Kulkarni, S., P.S. Abraham, N. Mohanty, N.N. Kadam, and M. Thakur. 2018. Sustainable Raft Based Hydroponic System for Growing Spinach and Coriander. Springer International AG, pp.: 117-125

Lingga, L. 2010. Cerdas Memilih Sayuran. Jurnal Agronomi 7(2): 6-8.

Morard, P., dan J. Silvestre. 1996. Plant Injury Due to Oxygen Deficiency in The Root Environment of Soilless Culture: A Review. Plant and Soil Vol. 184:243-254.

Muchtar, A.F. 2010. Panduan Praktis Strategi Memenangkan Persaingan Usaha dengan Menyusun Business Plan. Elex Media Komputindo, Jakarta.

Nappu, B dan F. Arief. 2012. Budidaya Sayuran di Lahan Pekarangan. BPTP Sulawesi Selatan. Available at http://sulsel.litbang. deptan.go.id.

Pemerintah Kota Bekasi. 2020. Kondisi Geografis Wilayah Kota Bekasi. Online: https://www.bekasikota.go.id/pages/kon disi-geografis-wilayah-kota-bekasi. (Diakses pada 31 Agustus 2020)

Samad, M. Y. 2006. Pengaruh penanganan pasca panen terhadap mutu komoditas hortikultura. Sains Dan Teknologi Indonesia, 8(1), 31-36.

Santoso, E. B. dan R. R. Widya. 2014. Gerakan Pertanian Perkotaan dalam Mendukung Kemandirian Masyarakat di Kota Surabaya. Seminar Nasional CITIES.

Septariarini, D.N., A. Herawati, Mujiyo. .2019. Pemanfaatan berbagai tanaman refugia sebagai pengendali hama alami pada tanaman cabai (Capsicum annum L.). Prima, 3(1): 1-9.

Wachjar, A., dan R. Anggayuhlin. 2013. Peningkatan produktivitas dan efisiensi konsumsi air tanaman bayam (Amaranthus tricolor L.) pada teknik hidroponik melalui pengaturan populasi tanaman. Departemen Agronomi dan Hortikultura Fakultas Pertanian. Institut Pertanian Bogor. Bogor. Bul. Agrohorti 1(1):127-134.

Zulfitri. 2005. Analisis Jenis Dan Polybag Terhadap Pertumbuhan Serta Hasil Cabai (Capsicum Annum L.) Sistem Hidroponik. Bulletin Penelitian (8):1-10. 